\title{
Impact of the type of mask on the effectiveness of and adherence to continuous positive airway pressure treatment for obstructive sleep apnea*
}

\author{
O impacto do tipo de máscara na eficácia e na adesão ao tratamento com \\ pressão positiva contínua nas vias aéreas da apneia obstrutiva do sono \\ Rafaela Garcia Santos de Andrade, Vivien Schmeling Piccin, \\ Juliana Araújo Nascimento, Fernanda Madeiro Leite Viana, \\ Pedro Rodrigues Genta, Geraldo Lorenzi-Filho
}

\begin{abstract}
Continuous positive airway pressure (CPAP) is the gold standard for the treatment of obstructive sleep apnea (OSA). Although CPAP was originally applied with a nasal mask, various interfaces are currently available. This study reviews theoretical concepts and questions the premise that all types of interfaces produce similar results. We revised the evidence in the literature about the impact that the type of CPAP interface has on the effectiveness of and adherence to OSA treatment. We searched the PubMed database using the search terms "CPAP", "mask", and "obstructive sleep apnea". Although we identified 91 studies, only 12 described the impact of the type of CPAP interface on treatment effectiveness $(n=6)$ or adherence $(n=6)$. Despite conflicting results, we found no consistent evidence that nasal pillows and oral masks alter OSA treatment effectiveness or adherence. In contrast, most studies showed that oronasal masks are less effective and are more often associated with lower adherence and higher CPAP abandonment than are nasal masks. We concluded that oronasal masks can compromise CPAP OSA treatment adherence and effectiveness. Further studies are needed in order to understand the exact mechanisms involved in this effect.
\end{abstract}

Keywords: Sleep apnea, obstructive; Continuous positive airway pressure; Masks.

\section{Resumo}

0 tratamento com continuous positive airway pressure (CPAP, pressão positiva continua nas vias aéreas) é o padrão ouro na apneia obstrutiva do sono (AOS). Apesar de a CPAP ter sido originalmente aplicada através de máscara nasal, várias interfaces são atualmente disponíveis. Revisamos conceitos teóricos e questionamos a premissa de que todas as máscaras produzem resultados semelhantes. Compilamos as evidências na literatura sobre o impacto do tipo de máscara na eficácia e na adesão ao tratamento com CPAP em pacientes com AOS. Foram pesquisados artigos escritos em inglês na base de dados PubMed com as palavras-chave "CPAP', "mask" e "obstructive sleep apnea". Dos 91 artigos encontrados, somente 12 foram selecionados por descrever o impacto do tipo de máscara sobre a efetividade $(n=6)$ ou a adesão $(n=6)$ ao tratamento. Apesar de alguns resultados conflitantes, não encontramos efeitos significativos da máscara pillow nasal e da máscara oral na eficácia ou adesão ao tratamento da AOS. Em contraste, a maior parte dos estudos mostrou que a máscara oronasal é menos efetiva e mais frequentemente associada a menor adesão e maior abandono do tratamento do que a máscara nasal. Concluímos que a máscara oronasal pode comprometer a eficácia e a adesão ao tratamento da AOS com CPAP. Estudos futuros são necessários para a compreensão dos mecanismos exatos envolvidos neste efeito.

Descritores: Apneia do sono tipo obstrutiva; Pressão positiva contínua nas vias aéreas; Máscaras.

\section{Introduction}

Obstructive sleep apnea (OSA) is characterized by repeated episodes of partial pharyngeal obstruction (hypopnea) or complete pharyngeal obstruction (apnea) associated with oxygen desaturation and sleep fragmentation. ${ }^{(1,2)}$ Polysomnography is the gold standard for the diagnosis of OSA,

*Study carried out in the Sleep Laboratory, Department of Pulmonology, Heart Institute, University of São Paulo School of Medicine Hospital das Clínicas, São Paulo, Brazil.

Correspondence to: Geraldo Lorenzi Filho. Laboratório do Sono, Instituto do Coração, Hospital das Clínicas, Faculdade de Medicina da Universidade de São Paulo, Avenida Dr. Enéas de Carvalho Aguiar, 44, $7^{\circ}$ andar, CEP 05403-000, São Paulo, SP, Brasil.

Tel. 5511 2661- 5486. E-mail: geraldo.lorenzi@incor.usp.br

Financial support: None.

Submitted: 8 May 2014. Accepted, after review: 27 June 2014. 
and the main parameter is the apnea-hypopnea index $(\mathrm{AHI})$, which indicates the number of apnea and hypopnea events per hour of sleep. In a recent study, in which a representative sample of patients in the city of São Paulo, Brazil, underwent polysomnography $(n=1,042)$, it was found that approximately one in every three adults (32.8\%) met the criteria for OSA syndrome, characterized by an $\mathrm{AHl}$ of more than 5 events/hour of sleep with symptoms or an $\mathrm{AHI}$ of more than 15 events/ hour of sleep with or without symptoms. ${ }^{(3)}$ The consequences of OSA are many, including sleep fragmentation, nonrestorative sleep, excessive daytime sleepiness, impaired quality of life, and increased cardiovascular complications, such as systemic arterial hypertension, cardiac arrhythmia, and increased risk of mortality. ${ }^{(4-9)}$

Application of continuous positive airway pressure (CPAP) during sleep is the gold standard for the treatment of patients with moderate to severe OSA. In patients with OSA, treatment with CPAP can reduce excessive daytime sleepiness, ${ }^{(10,11)}$ improve cognitive function, improve quality of life, ${ }^{(11)}$ reduce blood pressure in those with hypertension, and reduce the risk of cardiovascular morbidity and mortality. ${ }^{(12,13)}$ The efficacy of the treatment depends on the use of CPAP each night during sleep. ${ }^{(14)}$ However, adherence to CPAP therapy is extremely variable (46-80\%). ${ }^{(15,16)}$ Predictors of adherence to CPAP therapy include the severity of OSA, the degree of daytime sleepiness, the socioeconomic status, the level of patient understanding of the therapy, and the type of mask used. ${ }^{(17-20)}$

Treatment of OSA with CPAP was first described by Sullivan et al. in 1981.(21) The key idea was that CPAP applied with a nasal mask acted as a pneumatic splint to maintain upper airway patency, moving the soft palate anteriorly. An increasing number of masks that are lighter and more comfortable are becoming available for use in patients with nasal obstruction. Currently available types of masks include nasal masks, nasal pillows, oronasal masks, and oral masks (Figure 1). Nasal masks cover only the nose and must surround it so as not to compress the nasal alae, sitting just above the upper lip and near the angle of the eye. Nasal pillows consist of two nasal inserts and have emerged as an alternative to nasal masks because they are smaller and have less contact

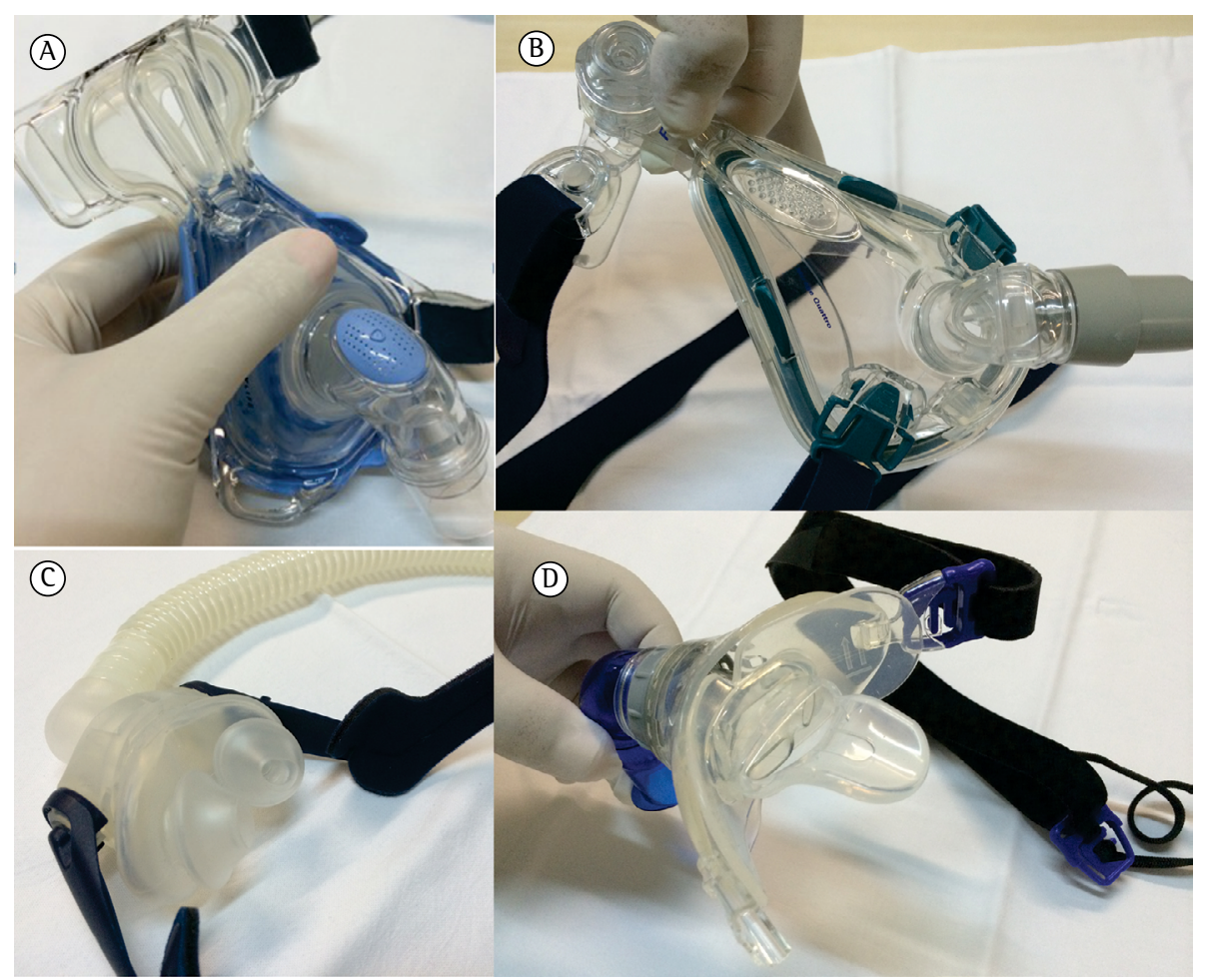

Figure 1 - Photographs showing the types of continuous positive airway pressure masks currently available for the treatment of obstructive sleep apnea: nasal mask, in A; oronasal mask, in B; nasal pillows, in C; and oral mask, in D. Source: Sleep Laboratory, Heart Institute, University of São Paulo School of Medicine Hospital das Clínicas. 
with the face. Oronasal masks cover the nose and the mouth and allow patients to breathe through their nose and their mouth. Oronasal masks were initially described for noninvasive ventilation in patients with respiratory failure and high ventilatory demand. ${ }^{(22)}$ Oronasal masks are considered an option for OSA patients with complaints of nasal obstruction and mouth breathing. ${ }^{(23-25)}$ Oral masks are made of silicone and resemble a butterfly, sitting between the lips and teeth. Oral masks include a tongue guide designed to hold the tongue in place and prevent it from blocking the flow of air from the CPAP. In clinical practice, oral masks are not widely used. With the objective of improving CPAP treatment adherence, a variety of materials are used in the manufacture of CPAP masks, including silicone, gel, and fabrics. A Google search returns approximately $1,600,000$ results for the search terms "nasal mask", "oronasal mask", and "nasal pillows"; this illustrates the diversity of interfaces and materials that are currently available. Despite this diversity, the level of scientific evidence for the efficacy of new models and their impact on treatment adherence have been questioned. In the present review, we sought to answer two questions: Can the type of mask affect the efficacy of CPAP treatment for OSA? Can it influence adherence to CPAP treatment?

\section{The impact of the type of interface on the efficacy of OSA treatment with CPAP}

The mechanisms of airway obstruction in patients with OSA and the effects of CPAP can be explained by the Starling resistor model. The Starling resistor consists of two rigid tubes connected by a collapsible tube. The two rigid tubes represent the nose and the trachea, which are bony and cartilaginous structures. The pharynx, which is a collapsible, muscular tube, lies between the two. In this model, the pharyngeal critical pressure is the pressure at which complete pharyngeal collapse occurs. ${ }^{(26)}$ The trend toward pharyngeal collapse depends on nasal and tracheal pressure, as well as on the pressure surrounding the pharynx. The fundamental concept is that the pressure that nasal CPAP applies to the pharyngeal lumen is greater than the pharyngeal critical pressure, thus ensuring pharyngeal patency (Figure 2). It is of note that the Starling resistor model involves variations in nasal pressure. It is clear that the model assumes that the mask is nasal rather than oronasal. Accordingly, Sullivan et al. proposed that CPAP be applied via a nasal mask when they first described the treatment of OSA with CPAP. ${ }^{(21)}$ Although it works, the application of CPAP via an oronasal mask for the treatment of OSA violates the principles of the Starling resistor model (Figure 2) and those of the model originally described by Sullivan et al. (Figure 3). From a conceptual standpoint, the pressure that opens the pharynx when applied nasally can also lead to pharyngeal collapse when applied orally.

The efficacy of oronasal masks can be questioned on theoretical and experimental grounds. Upper airway resistance during sleep and the propensity for obstructive apneas are significantly greater during mouth breathing than during nasal breathing. ${ }^{(27)}$ A study of 6 patients with severe OSA ${ }^{(28)}$ showed that the pressure required to maintain upper airway patency with the use of a nasal mask was insufficient to maintain upper airway patency when an oronasal mask was used. A study of 11 patients with OSA showed that oropharyngeal resistance was higher with the use of an oronasal mask than with the use of a nasal mask or a nasal mask with a mandibular advancement device. ${ }^{(29)}$ The deleterious effect of the oronasal mask was reversed by concomitant use of the mandibular advancement device. Therefore, the authors of that study hypothesized that the increased resistance observed with the use of an oronasal mask was caused by posterior tongue displacement. This hypothesis was confirmed in a study of two patients with Down syndrome, ${ }^{(30)}$ in whom CPAP applied via an oronasal mask resulted in posterior tongue displacement and reduced upper airway patency. We have recently reported the case of a 69-year-old male patient with severe OSA and persistent sleepiness, despite adequate use of CPAP applied with an oronasal mask. ${ }^{(31)}$ We conducted an oronasal CPAP titration study and found a residual $\mathrm{AHl}$ of 32 events/hour of sleep, despite the fact that CPAP was gradually increased to $16 \mathrm{cmH}_{2} \mathrm{O}$. A new CPAP titration study confirmed that the interface was affecting the efficacy of CPAP; we found that a nasal CPAP of $7 \mathrm{cmH}_{2} \mathrm{O}$ was enough to eliminate OSA in the first half of the study. The nasal mask was changed to an oronasal mask during the second half of the study, and the latter was found to be ineffective in eliminating OSA. In order to 


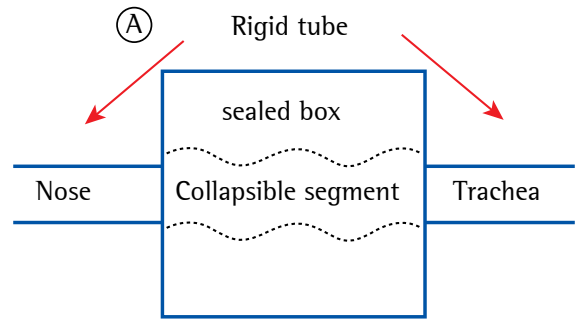

(C) Nasal CPAP $15 \mathrm{cmH}_{2} \mathrm{O}$

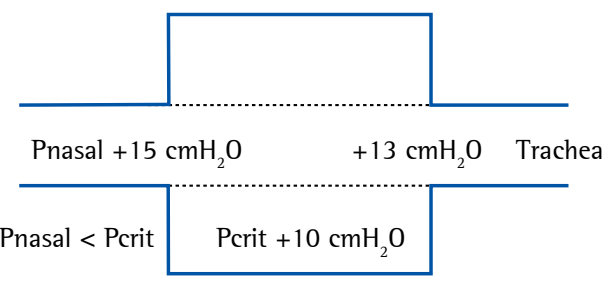

(B) Collapse (without CPAP)

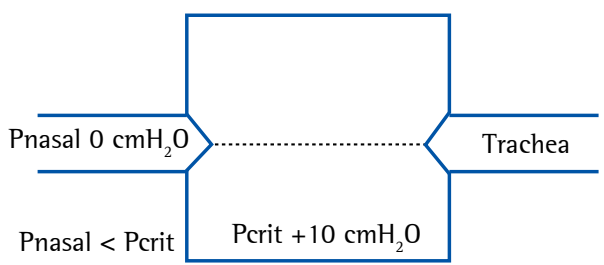

(D) Oronasal CPAP $15 \mathrm{cmH}_{2} \mathrm{O}$

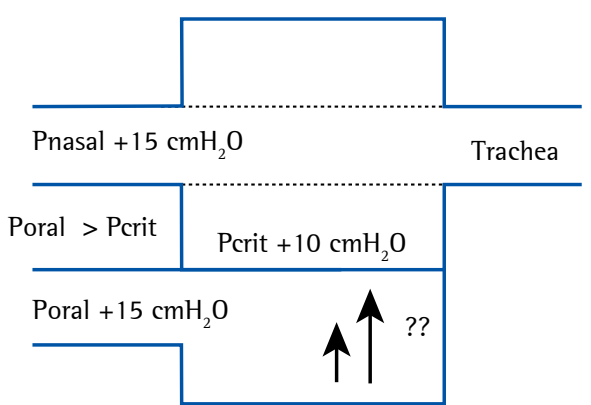

Figure 2 - Schematic illustration of the Starling resistor. In A, the nose and the trachea are represented by two rigid tubes connected by a collapsible segment (the pharynx). In B, pharyngeal collapse occurs when the pharyngeal critical pressure (Pcrit) is greater than the upper airway pressure (Pnasal). In C, nasal continuous positive airway pressure (CPAP) applied to the upper airway is greater than Pcrit and can therefore maintain upper airway patency. In D, oronasal CPAP; the hypothesis is that upper airway collapse occurs when oral pressure (Poral) is greater than Pcrit. Source: Sleep Laboratory, Heart Institute, University of São Paulo School of Medicine Hospital das Clínicas.
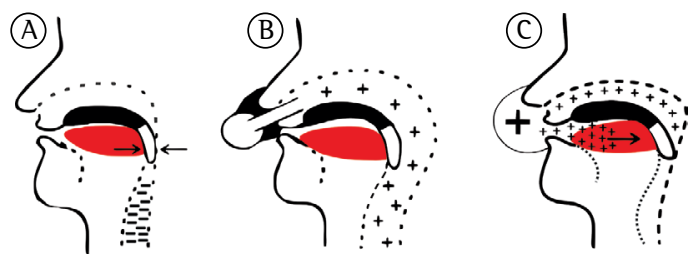

Figure 3 - $\ln$ A, schematic illustration of the normal upper airway (left) of a patient with obstructive sleep apnea, showing retropalatal obstruction during negative pressure generated during inhalation (center) and during continuous positive airway pressure (right). In B, schematic illustration of a patient wearing an oronasal mask, and, in C, patient with significant mouth breathing. The tongue (red) is displaced posteriorly and obstructs the upper airway. Adapted from Sullivan et al. ${ }^{(21)}$ Source: Schorr et al. ${ }^{(31)}$

clarify the mechanisms involved in this apparent paradox, we conducted a CPAP titration study during midazolam-induced sleep. ${ }^{(31)}$ The mask was customized to allow passage of the endoscope for direct visualization of the oropharynx. As expected, a nasal CPAP of $7 \mathrm{cmH}_{2} \mathrm{O}$ opened the oropharynx during sleep. In contrast, the oropharynx was found to be partially obstructed by posterior displacement of the base of the tongue with the use of an oronasal CPAP of 16 $\mathrm{CmH}_{2} \mathrm{O}$ (Figure 4). ${ }^{(32)}$ In that patient, oral CPAP caused posterior tongue displacement, which affected the efficacy of nasal CPAP. The case of that patient does not appear to be unique; our observations are couched in a solid theoretical framework and are corroborated by the findings of several experimental studies, prompting us to conduct the present literature review.

\section{Methods}

We searched the PubMed database using the search terms "CPAP", "mask", and "obstructive sleep apnea". The process of selection of articles for the review was divided into three stages. First, we selected the titles of interest. Second, we analyzed the abstracts of the selected articles to ensure that the studies addressed the impact of the type of CPAP mask on OSA treatment adherence, efficacy, or both. Although we thus identified 91 studies, only 12 met the inclusion 


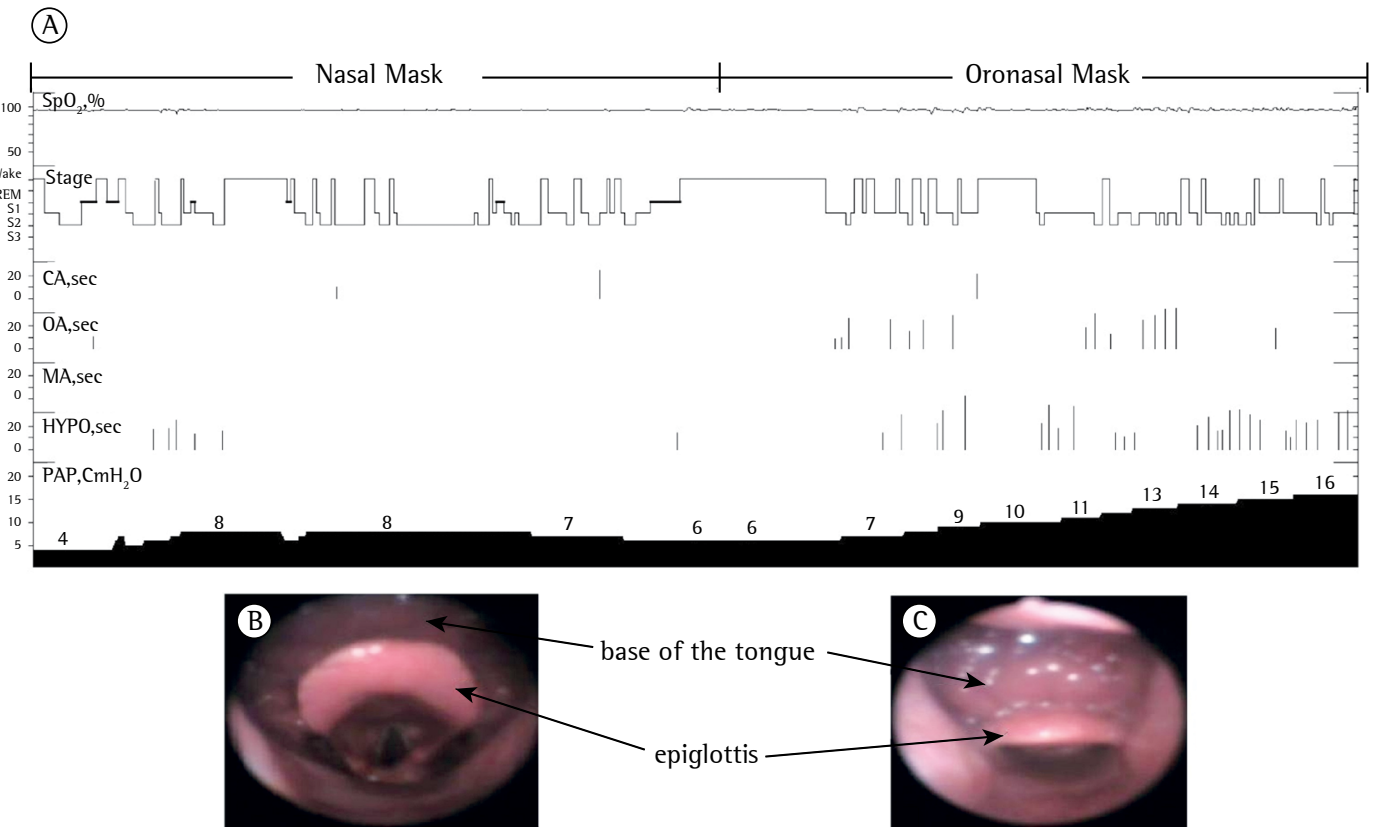

Figure 4 - In A, polysomnography summary of a continuous positive airway pressure (CPAP) titration study during natural sleep. In B and C, sleep endoscopy images showing the patient wearing a nasal mask and an oronasal mask, respectively. During the first half of the CPAP titration study, a nasal CPAP of $7 \mathrm{cmH}_{2} 0$ was enough to control obstructive events. During the second half of the CPAP titration study, an oronasal mask was used. Obstructive events persist, despite the fact that the pressure was gradually increased to $16 \mathrm{cmH}_{2} \mathrm{O}$. The endoscopic image obtained when a nasal CPAP of $7 \mathrm{cmH}_{2} \mathrm{O}$ was used (B) shows that the oropharynx is open. In contrast, the image obtained when an oronasal CPAP of $16 \mathrm{cmH}_{2} \mathrm{O}$ was used (C) shows posterior displacement of the base of the tongue, which pushes the epiglottis and significantly narrows the airway lumen. Respiratory events are expressed in seconds (sec). $\mathrm{SpO}_{2}$ measured by pulse oximetry. CA: central apnea; OA: obstructive apnea; MA: mixed apnea; Hypo: hypopnea; PAP: pulmonary artery pressure; and REM: rapid eye movement.

criteria. A study comparing nasal and oronasal masks in only 5 patients receiving CPAP was inconclusive and was therefore not included in the final analysis. ${ }^{(33)}$ Of the 12 studies included in the review, 6 described the impact of the type of CPAP interface on treatment efficacy. Of those, 2 also addressed treatment adherence and were therefore analyzed in conjunction with the 6 studies describing the impact of the type of CPAP interface on treatment adherence. The included articles were divided into observational studies and randomized studies.

\section{Impact of the type of mask on the efficacy of OSA treatment with CPAP}

We found 6 studies evaluating the efficacy of CPAP masks in the treatment of OSA. Table 1 shows an overview of the studies. Of the 6 studies, 3 were observational studies ${ }^{(34-36)}$ and 3 were randomized studies. Of those, 2 were crossover studies $^{(37,38)}$ and 1 was an open-label study. ${ }^{(39)}$ Comparisons were made between nasal masks and oronasal masks, in 3 studies $^{(36-38)}$; among nasal masks, oronasal masks, and nasal pillows, in $2^{(35,39)}$; and among nasal masks, oronasal masks, and oral masks, in $1 .^{(34)}$

The patients included in the 3 observational studies reviewed here had moderate to severe OSA. Beecroft et al. ${ }^{(34)}$ studied 98 patients, who were shown nasal masks, oronasal masks, and an oral mask for CPAP treatment and were allowed to choose one. Most (66\%) of the patients chose a nasal mask, whereas $27 \%$ chose the oral mask $(27 \%)$ and $7 \%$ chose an oronasal mask. Although the three groups of patients were similar in terms of anthropometric measurements and OSA severity, optimal CPAP (as determined by a CPAP titration study) was on average $2 \mathrm{cmH}_{2} \mathrm{O}$ higher and the residual AHI was on average 3 events/hour of sleep higher in those who used an oronasal mask than in those who used a nasal mask. Although the difference was not statistically significant, all parameters were worse in those who used 
Table 1 - Studies examining the efficacy of continuous positive airway pressure masks in the treatment obstructive sleep apnea.

\begin{tabular}{|c|c|c|c|c|c|c|c|}
\hline Study & Type of study & $\begin{array}{c}\text { Patients, } \\
n\end{array}$ & $\begin{array}{l}\text { Types } \\
\text { of } \\
\text { masks }\end{array}$ & $\begin{array}{l}\text { Baseline } \\
\text { AHl, } \\
\text { events/h }\end{array}$ & $\begin{array}{l}\text { Residual AHI, } \\
\text { events/h }\end{array}$ & $\mathrm{CPAP}, \mathrm{mmH}_{2} \mathrm{O}$ & Performance \\
\hline $\begin{array}{l}\text { Beecroft } \\
\text { et al. }{ }^{(34)}\end{array}$ & $\begin{array}{l}\text { Observational } \\
\text { study }\end{array}$ & 98 & $\begin{array}{l}\mathrm{N}, \mathrm{ON}, \\
\text { and } 0\end{array}$ & $\begin{array}{l}40.6 \pm \\
25.8\end{array}$ & $\begin{array}{l}\mathrm{N}: 6.7 \pm 13.3 ; 0 \mathrm{ON}: \\
9.8 \pm 12.8 ; 0: 10.9 \\
\pm 20.1 \\
\text { (ns) }\end{array}$ & $\begin{array}{l}\mathrm{N}: 7.7 \pm 2.1 ; 0 \mathrm{~N}: \\
9.7 \pm 3.2 ; 0: 8.8 \\
\pm 2.0 \\
\text { (ns) }\end{array}$ & $\mathrm{N} \approx 0 \mathrm{~N} \approx 0$ \\
\hline $\begin{array}{l}\text { Borel } \\
\text { et al. } .^{(35)}\end{array}$ & $\begin{array}{l}\text { Observational } \\
\text { study }\end{array}$ & 2,311 & $\begin{array}{l}\mathrm{N}, \mathrm{ON}, \\
\text { and NPs }\end{array}$ & $\begin{array}{l}41.0 \pm \\
21.0\end{array}$ & ND & $\begin{array}{l}\mathrm{N}: \approx 8.8 ; 0 \mathrm{~N}: \approx \\
9.6 ; \mathrm{NPs}: \approx 8.3 \\
\text { (p<0.05 for all) }\end{array}$ & $N P_{s}>N>0 N$ \\
\hline $\begin{array}{l}\text { Bettinzoli } \\
\text { et al. } .^{(36)}\end{array}$ & $\begin{array}{l}\text { Observational } \\
\text { study }\end{array}$ & 109 & $\mathrm{~N}$ and 0 & $\begin{array}{l}41.1 \pm \\
20.5\end{array}$ & $\begin{array}{l}\mathrm{N}: 2.6 \pm 2.5 ; 0 \mathrm{ON}: \\
4.5 \pm 4.4 \\
(\mathrm{p}<0.05)\end{array}$ & $\begin{array}{l}\mathrm{N}: 10.0 \pm 2.0 ; \mathrm{ON}: \\
11.2 \pm 2.1 \\
(\mathrm{p}<0.05)\end{array}$ & $\mathrm{N}>0 \mathrm{~N}$ \\
\hline $\begin{array}{l}\text { Teo } \\
\text { et al. }{ }^{(37)}\end{array}$ & $\begin{array}{l}\text { Randomized } \\
\text { crossover } \\
\text { study }\end{array}$ & 24 & $\mathrm{~N}$ and 0 & $\begin{array}{l}47.0 \pm \\
15.2\end{array}$ & $\begin{array}{l}N: 5.3 \pm 3.4 ; 0 N: \\
11.0 \pm 10.4 \\
(p=0.01)\end{array}$ & $\begin{array}{l}\mathrm{N}: 11.4 \pm 1.9 ; \mathrm{ON}: \\
11.8 \pm 2.4 \\
\text { (ns) }\end{array}$ & $\mathrm{N}>0 \mathrm{~N}$ \\
\hline $\begin{array}{l}\text { Bakker } \\
\text { et al. } .^{(38)}\end{array}$ & $\begin{array}{l}\text { Randomized } \\
\text { crossover } \\
\text { study }\end{array}$ & 12 & $\begin{array}{l}\mathrm{N}, \mathrm{ON}, \\
\text { and } \\
\mathrm{ON}+\mathrm{CS}\end{array}$ & $\begin{array}{l}59.8 \pm \\
28.6\end{array}$ & $\begin{array}{l}\text { N: } 0.61 \text { (IR: } 1.1) \text {; } \\
\text { ON: } 2.4 \text { (IR: 3.7): } \\
\text { ON+CS: 1.7 (IR: } \\
4.0) \\
(p=0.03 \text { for all) }\end{array}$ & $\begin{array}{l}\mathrm{N}: 11.0 ; 0 \mathrm{ON}: 11.1 ; \\
\text { ON+CS: } 11.1 \\
\text { (ns) }\end{array}$ & $\mathrm{N}>0 \mathrm{~N} \approx 0 \mathrm{~N}+\mathrm{CS}$ \\
\hline $\begin{array}{l}\text { Ebben } \\
\text { et al. }{ }^{(39)}\end{array}$ & $\begin{array}{l}\text { Randomized } \\
\text { open-label } \\
\text { study }\end{array}$ & 55 & $\begin{array}{l}\mathrm{N}, \mathrm{ON}, \\
\text { and NPs }\end{array}$ & ND & $\begin{array}{l}\Delta \mathrm{CPAP}(\mathrm{ON} \text { and } \\
\mathrm{N}): \\
\text { Moderate OSA: } \\
+2.8 \pm 2.1 ; \text { Severe } \\
\text { OSA }:+6.0 \pm 3.2 \\
(\mathrm{p}<0.001)\end{array}$ & ND & $\mathrm{N} \approx N P s>0 N$ \\
\hline
\end{tabular}

AHI: apnea-hypopnea index; CPAP: continuous positive airway pressure; N: nasal mask; ON: oronasal mask; 0: oral mask; NPs: nasal pillows; ON+CS: oronasal mask + chin strap; ND: no data; ns: not significant; IR: interquartile range;

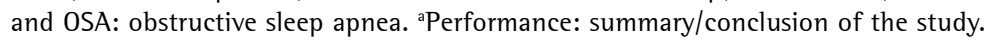

an oronasal mask. In addition, one third of the patients who initially chose an oronasal mask chose to change it to a different type of mask during follow-up. ${ }^{(34)}$ The oral mask also showed a trend toward a worse performance, the residual $\mathrm{AHI}$ being higher in those who used it than in those who used a nasal mask. Borel et al. ${ }^{(35)}$ conducted an observational cohort study of 2,311 OSA patients who had received a prescription for CPAP treatment and found that nasal masks, oronasal masks, and nasal pillows were used by $62 \%, 26 \%$, and $11 \%$, respectively. There were statistically significant differences among the three groups of patients regarding CPAP, which was higher in those who used oronasal masks than in those who used nasal masks, being higher in the latter than in those who used nasal pillows. In a multivariate analysis, oronasal masks were associated with subtherapeutic CPAP and low adherence to CPAP treatment (Table 2). ${ }^{(35)}$ Bettinzoli et al. ${ }^{(36)}$ evaluated 109 patients who were allowed to choose between nasal masks (67\%) and oronasal masks (42\%) for a home titration period of 3-4 nights with an automated CPAP device. Therapeutic CPAP and the residual $\mathrm{AHl}$ were significantly higher $\left(+1.2 \mathrm{cmH}_{2} \mathrm{O}\right.$ and +1.9 events $/ \mathrm{h}$, respectively) with the use of an oronasal mask. In a multivariate analysis, the oronasal mask was associated with higher pressure levels. ${ }^{(36)}$ The observational studies reviewed here showed that oronasal masks had the worst performance. The results of those studies should be interpreted with caution because they seem to suggest a potential lack of effectiveness with oronasal mask use.

In a randomized crossover study, Teo et al..$^{(37)}$ evaluated 24 patients with moderate to severe OSA and no history of oronasal surgery or signs of significant nasal obstruction. The therapeutic CPAP level as determined during titration was similar for nasal and oronasal masks. However, the residual $\mathrm{AHI}$ was on average 5.7 events/h higher with the use of an oronasal mask than with the use of a nasal mask $(p=0.01)$. The standard deviation of the residual $\mathrm{AHI}$ was on average 3 
Table 2 - Studies examining the impact of the types of masks on adherence to continuous positive airway pressure treatment.

\begin{tabular}{|c|c|c|c|c|c|c|}
\hline Study & $\begin{array}{l}\text { Type of } \\
\text { study }\end{array}$ & $\begin{array}{l}\text { Patients, } \\
\mathrm{n}\end{array}$ & $\begin{array}{l}\text { Types of } \\
\text { masks }\end{array}$ & $\begin{array}{l}\text { Baseline } \\
\text { AHI, } \\
\text { events/h }\end{array}$ & Treatment adherence & Performance $^{a}$ \\
\hline $\begin{array}{l}\text { Beecroft } \\
\text { et al. }{ }^{(34)}\end{array}$ & $\begin{array}{l}\text { Observational } \\
\text { study }\end{array}$ & 98 & $\mathrm{~N}, \mathrm{ON}$, and $\mathrm{O}$ & $40.6 \pm 25.8$ & $\begin{array}{l}\mathrm{Nights} / \text { week in the } \\
\text { acclimatization period: } \mathrm{N} \text { : } \\
5.8 \pm 1.7 ; 0 \mathrm{~N}: 3.8 \pm 3.0 ; 0: \\
6.6 \pm 0.8 \\
(\mathrm{p}<0.01 \text { for all })\end{array}$ & $\mathrm{N} \approx 0>0 \mathrm{~N}$ \\
\hline $\begin{array}{l}\text { Borel } \\
\text { et al. }{ }^{(35)}\end{array}$ & $\begin{array}{l}\text { Observational } \\
\text { study }\end{array}$ & 2,311 & $\mathrm{~N}, \mathrm{ON}$, and NPs & $41.0 \pm 21.0$ & $\begin{array}{l}\mathrm{N}: 5.7 \pm 2.2 \mathrm{~h} / \text { night; } 0 \mathrm{~N}: 5.1 \\
\pm 2.3 \mathrm{~h} / \text { night }(\mathrm{p}<0.0001)\end{array}$ & $\mathrm{N} \approx N P s>0 N$ \\
\hline $\begin{array}{l}\text { Bachour } \\
\text { et al. }{ }^{(40)}\end{array}$ & $\begin{array}{l}\text { Observational } \\
\text { study }\end{array}$ & 703 & $\mathrm{~N}, \mathrm{ON}$, and NPs & ND & $\begin{array}{l}\mathrm{N}: 5.8 \pm 2.8 \mathrm{~h} / \text { night; } 0 \mathrm{~N}: 4.7 \\
\pm 2.8 \mathrm{~h} / \text { night; NPs: } 4.7 \pm 3.2 \\
\mathrm{~h} / \text { night } \\
(\mathrm{p}<0.001 \text { for all) }\end{array}$ & $\mathrm{N}>\mathrm{NPs} \approx 0 \mathrm{~N}$ \\
\hline $\begin{array}{l}\text { Mortimore } \\
\text { et al. }{ }^{(20)}\end{array}$ & $\begin{array}{l}\text { Randomized } \\
\text { crossover } \\
\text { study }\end{array}$ & 20 & $\mathrm{~N}$ and $\mathrm{ON}$ & $34.0 \pm 5.2$ & $\begin{array}{l}\mathrm{N}: 5.3 \pm 0.4 \mathrm{~h} / \text { night; } 0 \mathrm{~N}: 4.3 \\
\pm 0.5 \mathrm{~h} / \text { night }(\mathrm{p}=0.01)\end{array}$ & $\mathrm{N}>0 \mathrm{~N}$ \\
\hline $\begin{array}{l}\text { Massie } \\
\text { et al. }{ }^{(42)}\end{array}$ & $\begin{array}{l}\text { Randomized } \\
\text { crossover } \\
\text { study }\end{array}$ & 39 & $\mathrm{~N}$ and NPs & $47.1 \pm 35.4$ & $\begin{array}{l}\text { \% days of use: } N: 85.7 \pm \\
23.5 \% \text {; NPs: } 94.1 \pm 8.3 \% \\
(p=0.02)\end{array}$ & $\mathrm{NPs}>\mathrm{N}$ \\
\hline $\begin{array}{l}\text { Ryan } \\
\text { et al. }{ }^{(43)}\end{array}$ & $\begin{array}{l}\text { Randomized } \\
\text { crossover } \\
\text { study }\end{array}$ & 21 & $\mathrm{~N}$ and NPs & $52.4 \pm 21.6$ & $\begin{array}{l}\mathrm{N}: 5.1 \pm 1.9 \mathrm{~h} / \text { night; NPs: } \\
5.0 \pm 1.7 \\
\text { (ns) }\end{array}$ & $N P s \approx N$ \\
\hline $\begin{array}{l}\text { Anderson } \\
\text { et al. }{ }^{(41)}\end{array}$ & $\begin{array}{l}\text { Randomized } \\
\text { crossover } \\
\text { study }\end{array}$ & 25 & $\mathrm{~N}$ and $\mathrm{O}$ & $85.0 \pm 36.0$ & $\begin{array}{l}\mathrm{N}: 3.8 \mathrm{~h} / \text { night; } 0: 3.5 \mathrm{~h} / \text { night } \\
\text { (ns) }\end{array}$ & $\mathrm{N} \approx 0$ \\
\hline $\begin{array}{l}\text { Khanna } \\
\text { et al. }{ }^{(44)}\end{array}$ & $\begin{array}{l}\text { Randomized } \\
\text { open-label } \\
\text { study }\end{array}$ & 38 & $\mathrm{~N}$ and 0 & $\begin{array}{l}N: 63.0 \pm \\
39.0 ; 0: \\
58.5 \pm 34.8\end{array}$ & $\begin{array}{l}\text { 1st month: } \mathrm{N}: 4.3 \pm 2.6 \mathrm{~h} / \\
\text { night; } 0: 4.6 \pm 2.1 \mathrm{~h} / \text { night } \\
\text { (ns) } \\
\text { 2nd month: } \mathrm{N}: 4.6 \pm 2.5 \mathrm{~h} / \\
\text { night; } 0: 5.5 \pm 2.6 \mathrm{~h} / \text { night } \\
\text { (ns) }\end{array}$ & $\mathrm{N} \approx 0$ \\
\hline
\end{tabular}

AHI: apnea-hypopnea index; N: nasal mask; ON: oronasal mask; 0: oral mask; NPs: nasal pillows; ND: no data; and ns:

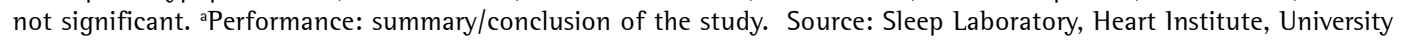
of São Paulo School of Medicine Hospital das Clínicas.

times higher with the oronasal mask (10.4 vs. 3.4 events/h), indicating a higher variability in the residual AHI. Arousals and leaks were also greater with the oronasal mask. ${ }^{(37)}$ Bakker et al. ${ }^{(38)}$ evaluated 12 patients with severe OSA and showed that changing from a nasal mask to an oronasal mask significantly increased leak and the residual $\mathrm{AHI}$; however, there was no difference between the two types of masks in terms of the CPAP level. Ebben et al. ${ }^{(39)}$ evaluated 55 patients with mild, moderate, or severe OSA. Patients were randomized to CPAP titration with a nasal mask, an oronasal mask, or nasal pillows. The nasal mask and nasal pillows were similar in terms of CPAP levels. Although the oronasal and nasal masks were similar in terms of the residual $\mathrm{AHI}$, the former required higher pressures than did the latter. This difference increased as the degree of OSA severity increased, being $+2.8 \pm 2.1 \mathrm{cmH}_{2} \mathrm{O}$ in patients with moderate OSA and +6.0 \pm 3.2 $\mathrm{cmH}_{2} \mathrm{O}$ in those with severe OSA. ${ }^{(39)}$ Therefore, all of the randomized studies reviewed here showed consistent results, showing that the performance of oronasal masks is worse than that of nasal masks. The studies also show that the performance of nasal pillows is similar to that of nasal masks.

\section{Impact of the type of mask on adherence to OSA treatment with CPAP}

We found 8 studies evaluating the impact of the type of mask on adherence to CPAP treatment 
(Table 2). As previously mentioned, 2 of the studies describing the impact of the type of mask on adherence to CPAP treatment also included relevant data on the impact of the type of mask on treatment efficacy, ${ }^{(34,35)}$ their characteristics being therefore described in Tables 1 and 2. Of the 8 included studies, 3 were observational studies $^{(34,35,40)}$ and 5 were randomized studies; of those, 4 were crossover studies ${ }^{(20,41-43)}$ and 1 was an open-label study. ${ }^{(44)}$ Comparisons were made between nasal and oronasal masks, in 1 study ${ }^{(20)}$; between nasal masks and nasal pillows, in $2^{(42,43)}$; between nasal and oral masks, in $2^{(41,44)}$; among nasal masks, nasal pillows, and oronasal masks, in $2^{(35,40)}$; and among nasal, oronasal, and oral masks, in $1 .^{(34)}$

The 3 observational studies reviewed here examined a total of 3,112 patients with moderate to severe OSA and showed lower adherence to CPAP treatment with the use of an oronasal mask than with the use of a nasal mask. ${ }^{(34,35,40)}$ Beecroft et al. showed that dropout rates were higher in patients receiving long-term CPAP applied via an oronasal mask than in those receiving long-term CPAP applied via a nasal mask. ${ }^{(34)}$ Treatment adherence was higher with the use of nasal pillows than with the use of nasal masks in one study ${ }^{(35)}$ but lower in another. ${ }^{(40)}$

In a randomized crossover study of 20 patients with moderate to severe OSA, Mortimore et al. ${ }^{(20)}$ initially performed CPAP titration with the use of a nasal mask and subsequently randomized patients to nasal CPAP or oronasal CPAP for 4 weeks each. Adherence to oronasal CPAP was approximately $1 \mathrm{~h}$ lower than adherence to nasal CPAP, and 19 of the 20 participants preferred the nasal mask. ${ }^{(20)}$ Oronasal masks have also been associated with poorer sleep quality, less slowwave sleep, more leaks, less satisfaction, and less comfort when compared with nasal masks. ${ }^{(37,38,42)}$

Two randomized crossover studies compared nasal masks and nasal pillows in terms of adherence to CPAP treatment. Massie et al. evaluated 39 OSA patients using nasal masks and nasal pillows for 3 weeks each and found that treatment adherence was significantly higher with the use of nasal pillows. ${ }^{(42)}$ Ryan et al. studied 21 severe OSA patients using nasal masks and nasal pillows for 4 weeks each. ${ }^{(43)}$ The authors found no differences between the two types of CPAP masks in terms of their impact on treatment adherence. However, the participants complained of nasal congestion, nasal dryness, nosebleeds, and headaches more frequently when they used nasal pillows than they did when they used nasal masks. ${ }^{(43)}$ Two studies showed that oral and nasal masks were similar in terms of their impact on treatment adherence. ${ }^{(41,44)}$ However, oral masks are not widely accepted and are rarely used in clinical practice.

\section{Final considerations}

We conclude that the type of mask can influence the efficacy of and adherence to CPAP treatment in patients with OSA. Nasal pillows constitute an alternative to nasal masks and appear to be effective in the treatment of OSA. Nasal pillows are lighter, and their initial acceptance might be higher. However, they can cause more nasal problems, particularly when a CPAP $>12 \mathrm{cmH}_{2} \mathrm{O}$ is used. A recent study showed that nasal pillows can be used even at pressures $\geq 12 \mathrm{cmH}_{2} \mathrm{O} .{ }^{(45)}$ Oral masks appear to be effective in the treatment of OSA because they hold the tongue in place with a tongue guide; however, they are rarely used in clinical practice because their level of acceptance is low. Several theoretical and experimental studies have shown that oronasal masks can affect the efficacy of and adherence to OSA treatment with CPAP. ${ }^{(20,26,31,36,37)}$ In comparison with nasal masks, oronasal masks often require higher CPAP levels and are associated with a higher residual $\mathrm{AHI}$ and lower adherence to treatment. How can we treat OSA patients who breathe through their mouth either by habit or because of nasal obstruction? We believe that the first step is to treat their nasal obstruction, either clinically or surgically. Another important point is that mouth breathing does not necessarily mean that nasal masks are contraindicated. For example, there is evidence that the use of nasal CPAP leads to a change of habit, reducing mouth opening and the number of oral breaths. ${ }^{(40,46,47)}$ However, many patients adapt well to oronasal masks and show perfect OSA control. Our review suggests two conclusions: first, nasal interfaces (i.e., nasal masks and nasal pillows) should always be the first choice; second, patients using oronasal masks must be monitored because the risks of CPAP treatment failure, nonadherence, and discontinuation are higher. Further studies are needed in order to understand the exact mechanisms by which oronasal interfaces affect the efficacy of OSA treatment with CPAP. 


\section{References}

1. Sleep-related breathing disorders in adults: recommendations for syndrome definition and measurement techniques in clinical research. The Report of an American Academy of Sleep Medicine Task Force. Sleep. 1999;22(5):667-89.

2. Young T, Peppard PE, Gottlieb DJ. Epidemiology of obstructive sleep apnea: a population health perspective. Am J Respir Crit Care Med. 2002;165(9):1217-39. http:// dx.doi.org/10.1164/rccm.2109080

3. Tufik S, Santos-Silva R, Taddei JA, Bittencourt LR. Obstructive sleep apnea syndrome in the Sao Paulo Epidemiologic Sleep Study. Sleep Med, 2010. 11(5): p. 441-6. http://dx.doi.org/10.1016/j.sleep.2009.10.005

4. Baranchuk A. Sleep apnea, cardiac arrhythmias and conduction disorders. J Electrocardiol. 2012;45(5):50812. http://dx.doi.org/10.1016/j.jelectrocard.2012.03.003

5. Drager LF, Ladeira RT, Brandão-Neto RA, Lorenzi-Filho G, Bense-or IM. Síndrome da apneia obstrutiva do sono e sua relação com a hipertensão arterial sistêmica: evidências atuais. Arq Bras Cardiol. 2002;78(5):531-53. http:// dx.doi.org/10.1590/S0066-782X2002000500013

6. Marin JM, Carrizo SJ, Vicente E, Agusti AG. Long-term cardiovascular outcomes in men with obstructive sleep apnoea-hypopnoea with or without treatment with continuous positive airway pressure: an observational study. Lancet. 2005;365(9464):1046-53. http://dx.doi. org/10.1016/S0140-6736(05)71141-7

7. Lorenzi-Filho G, Genta PR, Pedrosa RP, Drager LF, Martinez D. Cardiovascular consequences of obstructive sleep apnea syndrome [Article in Portuguese]. J Bras Pneumol. 2010;36 Suppl 2:38-42.

8. Bruin PF, Bagnato Mda C. Cognitive impairment in obstructive sleep apnea syndrome [Article in Portuguese]. J Bras Pneumol. 2010;36 Suppl 2:32-7. http://dx.doi. org/10.1590/S1806-37132010001400010

9. Engleman HM, Martin SE, Kingshott RN, Mackay TW, Deary 1J, Douglas NJ. Randomized placebo controlled trial of daytime function after continuous positive airway pressure (CPAP) therapy for the sleep apnoea/hypopnea syndrome. Thorax. 1998;53(5):341-5. http://dx.doi. org/10.1136/thx.53.5.341

10. Jenkinson C, Davies RJ, Mullins R, Stradling JR. Comparison of therapeutic and subtherapeutic nasal continuous positive airway pressure for obstructive sleep apnoea: a randomized prospective parallel trial. Lancet. 1999;353(9170):2100-5. http://dx.doi.org/10.1016/ S0140-6736(98)10532-9

11. Giles TL, Lasserson TJ, Smith BH, White J, Wright J, Cates CJ. Continuous positive airway pressure for obstructive sleep apnoea in adults. Cochrane Database Syst Rev. 2006;(3):CD001106.

12. Sharma SK, Agrawal S, Damodaran D, Sreenivas V, Kadhiravan T, Lakshmy R, et al. CPAP for the metabolic syndrome in patients with obstructive sleep apnea. N Engl J Med. 2011;365(24):2277-86. http://dx.doi. org/10.1056/NEJMoa 1103944

13. Chai CL, Pathinathan A, Smith BJ. Continuous positive airway pressure delivery interfaces for obstructive sleep apnoea. Cochrane Database Syst Rev. 2006;(4):CD005308.

14. Weaver TE, Grunstein RR. Adherence to continuous positive airway pressure therapy: the challenge to effective treatment. Proc Am Thorac Soc. 2008;5(2):173-8. http:// dx.doi.org/10.1513/pats.200708-119MG

15. Kribbs NB, Pack Al, Kline LR, Smith PL, Schwartz AR, Schubert NM, et al. Objective measurement of patterns of nasal CPAP use by patients with obstructive sleep apnea. Am Rev Respir Dis. 1993;147(4):887-95. http:// dx.doi.org/10.1164/ajrccm/147.4.887

16. Pépin JL, Krieger J, Rodenstein D, Cornette A, Sforza E, Delguste $P$, et al. Effective compliance during the first 3 months of continuous positive airway pressure. A European prospective study of 121 patients. Am J Respir Crit Care Med. 1999;160(4):1124-9. http://dx.doi. org/10.1164/ajrccm.160.4.9802027

17. Weaver TE. Adherence to positive airway pressure therapy. Curr Opin Pulm Med. 2006;12(6):409-13. http://dx.doi. org/10.1097/01.mcp.0000245715.97256.32

18. Billings ME, Auckley D, Benca R, Foldvary-Schaefer N, lber C, Redline $\mathrm{S}$, et al. Race and residential socioeconomics as predictors of CPAP adherence. Sleep. 2011;34(12):1653-8.

19. Kohler M, Smith D, Tippett V, Stradling JR. Predictors of long-term compliance with continuous positive airway pressure. Thorax. 2010;65(9):829-32. http://dx.doi. org/10.1136/thx.2010.135848

20. Mortimore IL, Whittle AT, Douglas NJ. Comparison of nose and face mask CPAP therapy for sleep apnoea. Thorax. 1998;53(4):290-2. http://dx.doi.org/10.1136/ thx.53.4.290

21. Sullivan CE, Issa FG, Berthon-Jones M, Eves L. Reversal of obstructive sleep apnoea by continuous positive airway pressure applied through the nares. Lancet. 1981;1(8225):862-5. http://dx.doi.org/10.1016/ S0140-6736(81)92140-1

22. Barach AL, Martin J, Eckman M, Martin J. Positive pressure respiration and its application to the treatment of acute pulmonary edema. Ann Intern Med. 1938;12(6):75495. doi:10.7326/0003-4819-12-6-754 http://dx.doi. org/10.7326/0003-4819-12-6-754

23. Olsen KD, Kern EB, Westbrook PR. Sleep and breathing disturbances secondary to nasal obstruction. Otolaryngol Head Neck Surg 1981;89(5):804-10.

24. Lavie P. Rediscovering the importance of nasal breathing in sleep or, shut your mouth and save your sleep. J Laryngol Otol. 1987;101(6):558-63. http://dx.doi.org/10.1017/ S0022215100102245

25. Figueiredo AC, Lorenzi MC, Prezzoti S, Cabral MM, Sennes LU, Lorenzi-Filho G. Efeitos da pressão positiva contínua em vias aéreas sobre os sintomas nasofaríngeos em pacientes com a síndrome da apnéia obstrutiva do sono. J Bras Pneumol. 2004;30(6):535-9. http://dx.doi. org/10.1590/S1806-37132004000600008

26. Gold AR, Schwartz AR. The pharyngeal critical pressure. The whys and hows of using nasal continuous positive airway pressure diagnostically. Chest. 1996;110(4):107788. http://dx.doi.org/10.1378/chest.110.4.1077

27. Fitzpatrick MF, Mclean H, Urton AM, Tan A, O'Donnell $D$, Driver HS. Effect of nasal or oral breathing route on upper airway resistance during sleep. Eur Respir J. 2003;22(5):827-32. http://dx.doi.org/10.1183/09031 936.03.00047903

28. Smith PL, Wise RA, Gold AR, Schwartz AR, Permutt S. Upper airway pressure-flow relationships in obstructive sleep apnea. J Appl Physiol. 1998;64(2):789-95.

29. Borel J C, Gakwaya J F, Masse J F. Impact of CPAP interface and mandibular advancement device on upper 
airway mechanical properties assessed with phrenic nerve stimulation in sleep apnea patients Respir Physiol Neurobiol. 2012;183(2):170-6. http://dx.doi.org/10.1016/j. resp.2012.06.018

30. Flecker RJ Jr, Mahmoud M, McConnell K, Shott SR, Gutmark E, Amin RS. An adverse effect of positive airway pressure on the upper airway documented with magnetic resonance imaging. JAMA Otolaryngol Head Neck Surg. 2013;139(6):636-8. http://dx.doi.org/10.1001/ jamaoto.2013.3279

31. Schorr F, Genta PR, Gregório MG, Danzi-Soares NJ, Lorenzi-Filho G. Continuous positive airway pressure delivered by oronasal mask may not be effective for obstructive sleep apnoea. Eur Respir J. 2012;40(2):503-5. http://dx.doi.org/10.1183/09031936.00145111

32. Genta PR, Eckert DJ, Gregorio MG, Danzi NJ, Moriya HT, Malhotra A, et al. Critical closing pressure during midazolam-induced sleep. J Appl Physiol (1985). 2011;111(5):1315-22. http://dx.doi.org/10.1152/ japplphysiol.00508.2011

33. Prosise GL, Berry RB. Oral-nasal continuous positive airway pressure as a treatment for obstructive sleep apnea. Chest. 1994;106(1):180-6. http://dx.doi.org/10.1378/ chest.106.1.180

34. Beecroft J, Zanon S, Lukic D, Hanly P. Oral continuous positive airway pressure for sleep apnea: effectiveness, patient preference and adherence. Chest. 2003;124(6):2200-8. http://dx.doi.org/10.1378/ chest.124.6.2200

35. Borel JC, Tamisier R, Dias-Domingos S, Sapene M, Martin F, Stach B, et al. Type of mask may impact on continuous positive airway pressure adherence in apneic patients. PLoS One. 2013;8(5):e64382. http://dx.doi.org/10.1371/ journal.pone.0064382

36. Benttizoli M, Taranto-Montemurro L, Messineo L, Corda L, Redolfi S, Ferliga M, et al. Oronasal masks require higher levels of positive airway pressure than nasal masks to treat obstructive sleep apnea. Sleep Breath. 2014 Feb 15. [Epub ahead of print]

37. Teo M, Amis T, Lee S, Falland K, Lambert S, Wheatley J. Equivalence of nasal and oronasal masks during initial CPAP titration for obstructive sleep apnea syndrome. Sleep. 2011;34(7):951-5.

38. Bakker JP, Neil AM, Campbell AJ. Nasal versus oronasal continuous positive airway pressure masks for obstructive sleep apnea: a pilot investigation of pressure requirement, residual disease, and leak. Sleep Breath. 2012;16(3):70916. http://dx.doi.org/10.1007/s11325-011-0564-3

39. Ebben MR, Oyegbile T, Pollak CP. The efficacy of three different mask styles on PAP titration night. Sleep Med. 2012;13(6):645-9. http://dx.doi.org/10.1016/j. sleep.2012.02.004

40. Bachour A, Vitikainen P, Virkkula P and Maasilta P. CPAP interface: satisfaction and side effects. Sleep Breath. 2013;17(2):667-72. http://dx.doi.org/10.1007/ s11325-012-0740-0

41. Anderson FE, Kingshott RN, Taylor DR, Jones DR, Kline LR, Whyte KF. A randomized crossover efficacy trial of oral CPAP (Oracle) compared with nasal CPAP in the management of obstructive sleep apnea. Sleep. 2003;26(6):721-6.

42. Massie CA, Hart RW. Clinical outcomes related to interface type in patients with obstructive sleep apnea/hypopnea syndrome who are using continuous positive airway pressure. Chest. 2003;123(4):1112-8. http://dx.doi. org/10.1378/chest.123.4.1112

43. Ryan S, Garvey JF, Swan V, Behan R, McNicholas WT. Nasal pillows as an alternative interface in patients with obstructive sleep apnoea syndrome initiating continuous positive airway pressure therapy. J Sleep Res. 2011;20(2):367-73. http://dx.doi. org/10.1111/j.1365-2869.2010.00873.x

44. Khanna R, Kline LR. A prospective 8 week trial of nasal interfaces vs. a novel oral interface (Oracle) for treatment of obstructive sleep apnea hypopnea syndrome. Sleep Med. 2003;4(4):333-8. http://dx.doi.org/10.1016/ S1389-9457(03)00063-7

45. Zhu X, Wimms AJ, Benjafield AV. Assessment of the performance of nasal pillows at high CPAP pressures. J Clin Sleep Med. 2013;9(9):873-7.

46. Heinz K, Nilius G. Mouth breathing in obstructive sleep apnea prior to and during nasal continuous positive airway pressure. Respiration. 2008;76(1):40-5. http:// dx.doi.org/10.1159/000111806

47. Senny F, Maury G, Cambron L, Leroux A, Destiné J, Poirrier R. Mandible behavior in obstructive sleep apnea patients under CPAP treatment. Open Sleep J. 2012;5:1-5. http://hdl.handle.net/2268/129588

\section{About the authors}

\section{Rafaela Garcia Santos de Andrade}

Doctoral Student. Sleep Laboratory, Department of Pulmonology, Heart Institute, University of São Paulo School of Medicine Hospital das Clínicas, São Paulo, Brazil.

\section{Vivien Schmeling Piccin}

Research Physical Therapist. Sleep Laboratory, Department of Pulmonology, Heart Institute, University of São Paulo School of Medicine Hospital das Clínicas, São Paulo, Brazil.

\section{Juliana Araújo Nascimento}

Physical Therapist. Sleep Laboratory, Department of Pulmonology, Heart Institute, University of São Paulo School of Medicine Hospital das Clínicas, São Paulo, Brazil.

\section{Fernanda Madeiro Leite Viana}

Otolaryngologist and Sleep Specialist. Sleep Laboratory, Department of Pulmonology, Heart Institute, University of São Paulo School of Medicine Hospital das Clínicas, São Paulo, Brazil. 


\section{Pedro Rodrigues Genta}

Attending Physician. Sleep Laboratory, Department of Pulmonology, Heart Institute, University of São Paulo School of Medicine Hospital das Clínicas, São Paulo, Brazil; and Postdoctoral Student, Division of Sleep Medicine, Brigham and Women’s Hospital/ Harvard University, Boston (MA) USA.

\section{Geraldo Lorenzi-Filho}

Director. Sleep Laboratory, Department of Pulmonology, Heart Institute, University of São Paulo School of Medicine Hospital das Clínicas, São Paulo, Brazil. 